\title{
Victor Leontovitsch, The History of Russian Liberalism in Russia (Pittsburg, University of Pittsburg Press, 2012).
}

\section{This book is the English language translation of Leontovitsch's Geschichte des} Liberalismus in Russland, which was originally published in 1957. As an émigré historian who was forced to flee the Bolshevik Russia, Leontovitsch's interest in Russian liberalism is driven by the question of why Russia's development along the path of constitutional state and civil society had collapsed by 1917. The same question has long animated Russian scholarship in the West, and more recently, in post-Soviet Russia, whose historians seek to reassess Russian history from a non-Marxist perspective. However, it is precisely because Russian liberalism was politically weak and intellectually derivative that historians tend to bypass it for conservative or radical traditions. The omission of a chapter on Russian liberalism in Ruggiero's magisterial work The History of European Liberalism prompted Leontovitsch to rescue the subject from obscurity. For this Leontovich deserves much credit, as even today, more than fifty years after its first publication, his work remains the only attempt at the history of Russian liberalism.

Liberalism (and not just in Russia) is a notoriously difficult subject to deal with, largely because there is no agreement among historians as to its precise definition and the scope for national variations. With this controversy in mind, Leontovitsch opens up his book with a concise and lucid explanation of what he understands by liberalism and how the Russian variant differed from its Western counterpart. This is the most stimulating part of his work, which presents insightful generalizations, and which, to some extent, makes up for the conclusion that is unfortunately absent from the book. Leontovitsch defines liberalism as "a system that gives[] precedence to the individual and his rights" (2). This "individualistic" order is achieved through the rule of law and constitutional order, which guarantee civil and political freedoms, decentralization, and separation of powers. Leontovitsch is adamant that liberalism adopted only peaceful and gradualist means, seeking to preserve whatever is useful in the existing order and implement reforms only when and if historical conditions for change are present. Leontovitsch therefore, regards "conservative liberalism as true liberalism" (14). This Burkean perspective enables Leontovitsch to distinguish between liberalism and radicalism but makes it difficult to draw the clear line between liberal and conservative forces.

Leontovitsch then goes on to analyze major milestones and figures in the history of Russian liberalism from 1762 to 1914 (rather than 1917), when World War I disrupted "the normal life in Russia" (x). Leontovitsch limits his 
analysis to "those who made a real contribution to the spread of liberal ideas or the creation of liberal institutions in Russia" (ix). By "real" he essentially means 'practical', hence the inclusion in the history of Russian liberalism of such figures as Catherine II and Nicholas I who played a role in the establishment of legal consciousness and respect for property rights (if only for the nobility) in Russia.

This is a highly contentious approach, for it narrows down the scope of Russian liberal tradition by excluding those liberals (such as Kavelin and Granovsky) who were deprived of a chance to affect Russian politics in a practical way. At the same time, Leontovitsch goes too far in extending the conservative boundaries of Russian liberalism. As a result, he overstates the 'liberal' contribution of the Russian monarchs. Although he does seek to analyze their policies in a qualified manner, this often results in vague and self-contradictory statements, as, for instance, in the case of Catherine II who is classified (along with Michael Speransky) as a "liberal absolutist" (53). There have been more nuanced treatments of Catherine II and Speransky since the book was first published.

Leontovitsch's historicist viewpoint leads him to believe that the Russian government (especially under Alexander II and his grandson) was on its way to transforming Russia into a fully-fledged constitutional state and civil society. The main reason why this goal did not materialize is the radicalization of "the Russian intelligentsia," who demanded more than it was feasible within the context of the time. He writes, for instance, that the members of the “'Liberation movement'... were not interested in establishing mutual trust and normal cooperation between the representatives of government and the public at large" (220). In keeping with his conservative criteria, Leontovisch essentially includes into "the radical intelligentsia" anyone who stood to the left of what would become in 1905 the Octobrist party. More objectionably, he arrives at this conclusion after giving only a cursory treatment to Peter Struve and Pavel Novgorodtsev. Legal theorists Sergei Kotliarevsky and Bogdan Kistiakovsky are altogether absent from Leontovitsch's account.

Although Leontovitsch presents a few insightful observations (for instance, when he discusses the dilemma facing Russian autocrats who considered the emancipation of serfs), the book presents neither comprehensive nor balanced enough picture to close up the existing gap in Russian historiography. It may be of value as a history of Russian liberal institutions and civil society, but the intellectual history of Russian liberalism awaits its researcher. 